\title{
A. Montandon, Barbe-Bleue au théâtre des Variétés. Pour une littérature socio-poétique
}

\section{Maria Emanuela Raffi}

\section{(2) OpenEdition}

1 Journals

\section{Edizione digitale}

URL: http://journals.openedition.org/studifrancesi/10015

DOI: 10.4000/studifrancesi. 10015

ISSN: 2421-5856

\section{Editore}

Rosenberg \& Sellier

\section{Edizione cartacea}

Data di pubblicazione: 1 août 2017

Paginazione: 383

ISSN: 0039-2944

\section{Notizia bibliografica digitale}

Maria Emanuela Raffi, «A. Montandon, Barbe-Bleue au théâtre des Variétés. Pour une littérature sociopoétique», Studi Francesi [Online], 182 (LXI | II) | 2017, online dal 01 août 2017, consultato il 06 janvier 2021. URL: http://journals.openedition.org/studifrancesi/10015 ; DOI: https://doi.org/10.4000/ studifrancesi. 10015

Questo documento è stato generato automaticamente il 6 janvier 2021.

\section{(c)}

Studi Francesi è distribuita con Licenza Creative Commons Attribuzione - Non commerciale - Non opere derivate 4.0 Internazionale. 


\title{
A. Montandon, Barbe-Bleue au théâtre des Variétés. Pour une littérature socio- poétique
}

\author{
Maria Emanuela Raffi
}

\section{NOTIZIA}

ALAIN MONTANDON, Barbe-Bleue au théâtre des Variétés. Pour une littérature socio-poétique, «Romanistische Zeitschrift für Literaturgeschichte/Cahiers d'Histoire des Littératures Romanes», Winter 2016, pp. 111-126.

1 Rappresentata nel 1866, l'opera buffa Barbe-bleue di Offenbach realizza a un tempo una nuova parodia del popolare racconto di Perrault e un esercizio della «moquerie musicale» in voga nel xIX secolo. Il taglio della lettura critica di Montandon sonda tuttavia un'ulteriore aspetto, dato che la socio-poétique si prefigge «d'analyser la manière dont les représentations et l'imaginaire social informent le texte dans son écriture même». Le situazioni e le forme dell'opera di Offenbach offrono diversi spunti di riflessione: la vuota rigidità della Corte, l'inconsistenza delle promesse (matrimoniali, ma anche politiche), il servilismo dei cortigiani, la "commedia" dei rapporti sociali, tutto si sussegue in una serie di «allusions multiples et ridiculisantes». Ciò che rende tuttavia lo spettacolo accettabile e divertente è la "grâce souveraine de l'ironie» e il ritmo trascinante della musica che, impedendo una reale riflessione, allontanano dalla realtà e dalle drammatiche contraddizioni del Secondo Impero. La stessa assurda velocità con cui si succedono i matrimoni, sempre più ravvicinati, di Barbe-bleue, mentre strizza l'occhio alla nuova estetica della modernità, ne sgretola anche l'aspetto drammatico, giustificando il giudizio di Jules Lemaitre, da cui parte Montandon: «Ah! Cette opérette est bien dissolvante». 